\title{
Rape in World War II film: comparing narrations Tetyana DZYADEVYCH
}

\begin{abstract}
The objective of this paper is to show how the filmmaker's genre of choice shapes the main discourse of the film. The author compares Helke Sander's documentary Liberators Take Liberties (1991-1992) and Max Farberbock's narrative feature A Woman in Berlin (2008) both dealing with the dramatic effect of the end of WWII, in particular with the instances of German women having been raped by the Allied troops, a theme first publicized in the anonymous diary A Woman in Berlin (1953). There is a clear connection between the book and the two films, but if Sander focuses on the rape itself and on the extraordinary female experience of war, Farberbock is more concerned with cross-national revenge. The author looks closer at the genre elements, particularly at the genres of the diary, the (feminist) documentary, and the narrative film. Then, the author draws some parallels between the Helke Sander film and the diary A Woman of Berlin and discusses the documentaries within the feminist framework inspired by Sander's accomplishments.
\end{abstract}

Key-words: Second World War, documentary movies, women, diaries, feminism, rape

The same story reiterated in a different genre may take on a drastically different ideological meaning. The objective of this paper is to show how the filmmaker's genre of choice shapes the main discourse of her film. Even if two films are based on the same story, the preferred genre brings in its own ideological message and thus molds the movie's discourse. I will compare Helke Sander's documentary Liberators Take Liberties (1991-1992) and Max Farberbock's narrative feature A Woman in Berlin (2008) as both deal with the dramatic effect of the end of WWII, in particular with the instances of German women having been raped by the Allied troops - a theme first publicized in the anonymous diary A Woman in Berlin (1953). There is a clear connection between the book and the two films, but if Sander focuses on the rape itself and on the extraordinary female experience of war, Farberbock is more concerned with cross-national revenge.

First, I want to look closer at the genre elements, particularly at the genres of the diary, the (feminist) documentary, and the narrative film. Then I will draw some parallels between the Helke Sander film and the diary A Woman of Berlin. I will discuss the documentaries within the feminist framework inspired by Sander's accomplishments. In order to stress certain points, I will refer to some 
women's Berlin diaries from the war period. Finally, I will analyze the different narrative strategies and ideological agendas employed in Max Farberbock's film A Woman in Berlin, emphasizing the connection between the screen adaptation and the eponymous book. I will take into account the time of production and the historical circumstances under which the films were made.

\section{A Couple of Words on Genre and Gender}

This paper examines the modes in which different genres address the same historical occurrences: the end of WWII, the fall of the Third Reich, and the momentous female experience caught in this crossbeam. The main point of reference for this paper is Marta Hiller's diary, better known [for some time] as Anonymous' A Woman in Berlin (1953).

The diary as a genre comes in many guises: "actual or fictional, published or unpublished, private or public"1. Despite this multitude of permutations, however, the diary is still considered an ever-reliable, time-honored historical source $^{2}$. For example, a vast cluster of our knowledge about WWII has been culled from The War Diary by Field Marshal Lord Alanbrooke ${ }^{3}$. Some diaries are intended as private documents of self-reflection, others as a dialog with an imagined listener; most are beamed forward to the future generations, with a clear understanding that this writing will eventually gain public exposure. In this way, the author "makes a claim to personal selfhood and to authorial legitimacy"4.

The author's attitude necessitates different strategies of writing and reading: “... there is the feeling of the voyeur, peeping around pages as if they were curtains, searching out the secret thoughts and life recorded on the private page"s. It is the author who decides what to vocalize and what to elide, what deserves closer inspection and what may be glossed over. A filmmaker follows a similar trajectory while adapting a story for the screen. The reader receives the picture described by the author, while the spectator watches a preselected scene. In both cases, the point of view is manipulated by the author.

Manipulation of the addressee's perception occurs in any art form, but diaristic prose renders manipulation especially obvious inasmuch as it lays claim

1 Bernard Duyfhuizen, Narratives of Transmission (Cranbury, NJ: Fairleigh Dickinson University Press, 1992), 75.

${ }^{2}$ http://suite101.com/article/diaries-and-historical-research-a200707 (Accessed 05.01.2013)

3 Viscount Alanbrooke, War Diaries (1939 - 1945) (Berkeley: University of California Press, 2001).

4 Irina Paperno, "Connecting the "I" and History", in Stories of the Soviet Experience. Memoirs, Diaries, Dreams (Ithaca: Cornell University Press, 2009), 17.

5 Duyfhuizen, Narratives, 75. 
to immediate personal expression. Duyfhuizen writes: "For diary narratives, we must add to the narrating and experiencing selves the reading self (italicized by the author - T.D.), the addressed "I" of the diarist/reader in a solipsistic characterized act of reading the narrating self's text of the experiencing self's life story". There are two coexisting perspectives in a diary: the author writes about herself and her surroundings as she invites the reader to see the entirety of the world through her eyes.

Inevitably, first-person narration elicits more empathy from the addressee. Suzanne Keen writes: “...the commonplace that the first person fiction more readily evokes feeling responsiveness than the whole variety of third person narrative situations... the category of first person narratives, empathy maybe enhanced or impeded by narrative consonance or dissonance, unreliability, discordance, an excess of narrative levels with multiply narrators..."7. This effect of first-person narration in fiction is achieved because the reader trusts the I-story as if it were an intimate confession. The diary deepens this essential trust with its built-in presumption of authenticity.

However, David Goldknoff plays the devil's advocate by saying, “...we want first to have answered the question of whether the "I" is real or imaginary... we must know a good deal about I (who may, after all, be a dreadful liar) to evaluate that he tells us... There is something fake about I, and that is the illusion of autonomy which he seeks to project" 8 . The recipient implicitly wishes to trust the first-person narrator, and at the same time, she is looking for evidence or sources of objectification.

In a movie, this objectification can be reached by providing an additional perspective, one that contemporary film studies define as "camera eye," "firstdegree narrator," or primary narrative agency". These terms signify the intensive work of the camera which furnishes supplementary points of view and allows to complement the I-narration with external angles.

The issue of subjective and objective narration is closely connected with the female forms in the genre system--diaries, memoirs, and letters--as opposed to such male forms as high tragedy, epic poetry, and sermons ${ }^{10}$.

6 Duyfhuizen, Narratives, 177.

7 Suzanne Keen, "A Theory of Narrative Empathy" in Narrative, Vol. 14, No. 3 (October 2006): 215.

8 David Goldknoff, “The Confessional Increment: A New Look at the I-Narrator," The Journal of Aesthetics and Art Criticism, Vol. 28, No 1 (Fall, 1969): 13-14.

9 Johann N. Schmidt, Narration in Film - the living handbook of narratology, Hamburg University Press. Http://hup.sub.uni-hamburg.de/lhnn/index.php?title=Narration in Film\&oldid=1988 (Accessed: 22 January 2013).

${ }^{10}$ Mary Eagleton, “Genre and Gender," in Modern Genre Theory (London: Longman 2000), 252. 
According to this classification, it is important to treat the genre of the diary, as well as documentary and oral history interview, as a longing for feminine selfexpression, whereas the masculine form is oriented toward the novel, national drama, and grand national narrative.

Film narration and its point of view are closely associated with the general ideological approach to film. It is an ideological attitude that directs the spectator's perception. George Wilson, in his work Narration in Light. Studies in Cinematic Point of View, muses: “... each of the films also offers the possibility of seeing how the whole of its action and the filmic presentation of the action could have been more thoroughly and coherently perceived in an altogether different vein if one's inertia in that space had not been total. One can literary learn to see that which was strictly invisible to us as long as even 'simple observation' was imbued with the ideological forms and habits that the context of our lives make standard"11. Therefore, the ideological message of a film consists not only of direct messages that the viewer receives from the screen, but also of the multiplicity of points of view that the spectator is invited to perceive in order to be an active observer. Thus, the editing and selecting of the type of narration create a special ideological tension and guide the perception of the addressees.

The point of view is what differentiates the main ideological claim of Helke Sander's feminist approach from that of Max Farberbock's nation-oriented portrayal of female destiny during the last days of WWII in Berlin.

\section{The Diary of A Berliner Woman and Documentaries Around It} A Woman in Berlin. Eight Weeks in the Conquered City was first published in 1953 in English in the USA. The book has since been translated into seven languages, but the first edition went virtually unnoticed in Germany in 1954. Five years later, there was another attempt to initiate discussion in Germany, when the book was republished in translation from the English-language version. No public debate followed, either, but as Hans Magnus Enzensberger mentions in his foreword to a recent reissue, the book influenced the young dissenters who participated in the protest movements of 1968. He writes: "By the seventies, the political climate had become more receptive, and photocopies of the text, which had long been out of print, began to circulate in Berlin among the radical students of 1968 and the burgeoning women's movement"12.

${ }^{11}$ George M. Wilson, "Narration in Light. Studies in Cinematic Point of View" (Baltimore, London: The Johns Hopkins University Press, 1988), 13.

${ }^{12}$ Hanz Magnus Enzensberger, „Foreword“, in A Woman in Berlin. Eight Weeks in the Conquered City. A Diary by Anonymous (New York: Metropolitan Books, 2005), xi. 
In general, there has always been a strong interest in the ego-documents of WWII. Almost every postwar decade produced outstanding testimonies of that crucial event. In 1942, Roy Publishers issued the war-diary Mermaid and the Messerschmitt, 1939-1940 by Rulka Langer. In 1947 the world was shocked by the first publication of The Diary of One Girl by Anna Frank. There were also some publications of the ego-documents that described life in Berlin during the WWII. Around the same time, Christabel Mary Burton's diary The Past Is Myself (1968) came out ${ }^{13}$. It was the diary of an English woman who married a German lawyer before the war and lived in Germany through the conflict, initially in Berlin with her family, then in a village in Schwarzwald.

The most interesting documents are the memoir of Tatiana Metternich, born Vassiltchikov (1976) ${ }^{14}$ and the war diary of her sister Marie Vassiltchikov $(1985)^{15}$. These documents merit especial attention, first and foremost, because they were written by two Russian young women of aristocratic origins who moved to Berlin from Lithuania in 1940, when the war with the USSR started looming large. While other family members were scattered all over Europe, the Vassiltchikov sisters stayed in Germany for the duration of the war.

All the authors of the above-mentioned documents, educated women of upper-class background, lived on the German side during WWII. Marta Hiller, the author of $A$ Berlin Woman (the publishers were granted permission to use her real name after her death in 2001), was a journalist. Before the war she had studied at Sorbonne, and had lived in Paris and in Moscow. She was fluent in French and spoke some Russian.

The Oxford-educated Christabel Bielenberg belonged to an aristocratic family with English-Irish roots. Before the war broke out, she went to Hamburg to study music and fell in love with a German lawyer, whom she soon married and whose German citizenship she assumed.

The Vassiltchikov sisters, as I have mentioned earlier, were Russian princesses from a White émigré family. During the war they worked for the Third Reich. Tatiana Vassiltchikov married the German aristocrat Paul Metternich. Neither sister ever expressed any regret. Between national and social identity, they chose the latter. Though they were not admirers of Hitler because of his mistrust of nobility, the USSR never played the sacred role of Motherland in their writing, either.

\footnotetext{
${ }^{13}$ Now this book is better known under the title When I Was a German, 1934-1945: An Englishwoman in Nazi Germany, (Lincoln: University of Nebraska Press, 1998).

${ }^{14}$ Tatiana Metternich, Purgatory of Fools. A Memoir of the Aristocrats' War in Nazi Germany (Quadrangle, New York: Times Book Co, 1976).

${ }^{15}$ Marie Vassiltchikov, Berlin Diaries, 1940-1945 (New York: Alfred A. Knopf, 1987).
} 
Having analyzed all these documents, I can chart the similarities in their patterns. All the authors write about the terrible experience of hiding underground in anticipation of a bombing. All the documents touch upon food shortages and hunger. The women were concerned about the destiny of their relatives, friends, and loved ones, which did not prevent them from thinking, simultaneously, about clothes as their physical appearance continued to matter to them in the direst straits. Frustrated with unsuccessful campaigns and bad news from the front-lines, they looked into the future with undisguised apprehension.

What sets Marta Hiller's text apart is the way it tackles the issue of mass rapes, escalated as the war drew to a close. It does not matter that Hiller was in Berlin only briefly. Unfortunately, in those days women were raped throughout the country. Even in the diaries and literary texts from the Soviet side of the conflict, one can find some inklings of that fact ${ }^{16}$, although most women kept silent about the brutal treatment they were subjected to during the liberation. Marta Hiller's book is unique insofar as it is unafraid to articulate what others wanted to consign to oblivion.

There is an internal link between the book and Helke Sander's documentary film Liberators Take Liberties (1991 - 1992). Both break the silence about a tragic moment in the past as they circumvent moral taboos and open themselves up to the possibility of otherness. Both writers assign an important role to the binary opposition of culture and nature, and speak more eloquently on behalf of womankind than of their nation.

A Woman in Berlin is not only a meticulous chronicle of what went on in Berlin from April $20^{\text {th }}$ till June $22^{\text {nd }} 1945$. It is also an astute analysis, a probe into why it happened and what consequences it entailed. Besides the actual instances of rape, the memoir also discusses the rowdy behavior of the Soviet soldiers, terrible unhygienic conditions, and absolute humiliation the women went through. It is with great bravery that the author commits to paper the palpable frustrations and lack of solidarity among her own people, thus intimating the actual value of educated women for the Soviet soldiery.

Without any hypocrisy, Hiller writes what happened to her on May $1^{\text {st }}$ and why she decided to ask a Soviet official for protection: "Suddenly his finger is on my mouth, stinking of horse and tobacco. I open my eyes. A stranger's

\footnotetext{
${ }^{16}$ By implication I touched this issue in: "Ukrainian sotsrealism literature in the European Discourse. Standard-bearers by Oles Gonchar (1946-1948)“ (in German), in Europa im Ostblock. Vorstellungen und Diskurse (1945-1991) / Europe in the Eastern Bloc. Imaginations and Discourses, eds. José M. Faraldo, Paulina Gulińska- Jurgiel, Christian Domnitz (Köln, Wien: Böhlau Verlag, 2008), 145-163.
} 
hands expertly pulling apart my jaws. Eye to eye. Then with great deliberation he drops a gob of gathered spit into my mouth....Damn this to hell! I say it loud. Then I make up my mind. No question about it: I have to find a single wolf to keep away the pack. An officer, as high-ranking as possible, a commandant, a general, whatever I can manage. After all, what are my brains for my little knowledge of enemy's language?"17 It is astonishing that, while utterly humiliated, the author did not lose her rational approach to reality and refused to remain continuously victimized.

From a formalist perspective, switching the tone of narration is the most interesting aspect of the diary. In detailing her everyday routine, the author incorporates increasingly broad ruminations on the causes and effects of the current situation. The narrator demonstrates a strong will to survive, which requires a better understanding of the invaders. She investigates them and looks for a rational explanation for their totally irrational behavior. One of the reasons for their brutality, according to Hiller, lies in the lack of the Western tradition of chivalry in Russia. She comes to a conclusion that echoes Herder's theory of Volksgeist ${ }^{18}$. She writes: "But I have the feeling that, deep inside, all these simple, undiscriminating men feeling insecure in front of me, despite their blustering. They are children of the people"19. Such an explanation might have a therapeutic effect and grants relief and symbolic power to the victim of repeated sexual assault. She also brings into the discourse the binary opposition between culture and nature, so pivotal to Helke Sander's film.

Regardless of all the war atrocities, Hiller sees a human being in the enemy, marked socially as well as ethnically. Not merely a faceless mob, these men have distinct identities, and sad personal stories lurk behind their indignities. It is this extreme attention to the other, frankness, and openness, among other things, that connect Marta Hiller's text to Helke Sander's documentary.

Thomas Elsaesser writes on Helke Sander's creative MO: "Between the suppression of the "personal" in left politics and its lustful or painful exhibition, Sander's films try to chart a different course, in so far as they do not pursue either side of the equation. Instead of compensating the deficit of identity by staging a masquerade, they dramatize the loss of self as a sort of 'bad timing'”20.

${ }^{17}$ A Woman in Berlin (New York: Metropolitan Books, 2005), 63-64.

${ }^{18}$ There is a huge list of bibliography on it in the Eastern European discourse and almost everybody who studies Slavic Romanticism studied Herder's ideas on the future of Slavs. I can mention one source here: http://www.counter-currents.com/2011/05/herders-theory-of-the-volksgeist/

${ }^{19}$ A Woman in Berlin, 70.

${ }^{20}$ Thomas Elsaesser, New German Cinema. A History (New Jersey: Rutgers University Press, 1989), 191. 
This statement was made before Sander's Liberators Take Liberties but it fits Sander's overarching mode of authorship.

As far as aesthetic devices are concerned, there is a clear correlation between Sander's films from the late 1960s-early 1970s and her subsequent work Liberators Take Liberties. Both position themselves in between documentary and art-house filmmaking, set to disturbing soundtracks, brimming with fanciful camera work, and prone to metaphorical expression. Sander did not make just a documentary or an oral history project; she framed it with elements of art-house fare as she had before, when the diary of Marta Hiller had been circulating among young people in Berlin. So in this way, Liberators Take Liberties can be considered a revival of the author's earlier interest in the work, when she did not have the resources to adapt such a controversial source.

Liberators Take Liberties was made at the right moment and now, in retrospect, appears eerily well-suited for the early 1990s. The collapse of the USSR and the resultant "wind of change" in Eastern Europe allowed Sander to travel to Minsk and to talk to people from the other side of the iron curtain. She went to Belarus, the former Soviet republic which had been dealt the most gruesome fate during WWII. One can only marvel at the filmmaker's bravery as she interviewed people on the tabooed subject of mass rape committed by the Soviet troops in Eastern Germany.

The first leader of the newly-born independent Belarus, Stanislaw Shushkevich, inaugurated a new political era in the country by opening the borders for foreigners and archives to the researchers. A project like Sander's would have met with much stronger resistance if it were undertaken in contemporary Belarus ${ }^{21}$. In a horrific historical irony, the film was also well-timed because it coincided with the civil-war massacre in Yugoslavia, accompanied by mass rape of civilians. Rape was used as a military tool and became a building block of the Bosnian genocide ${ }^{22}$.

Though nominally concerned with German history, the film turned out to be about much more than that. It brings into focus the feminist issues that Helke Sander scrutinized in her previous work. Using the current situation in Germany as her point of departure, Sander broached an array of general questions about being a woman, a mother, a single mother, and a working single mother.

${ }^{21}$ In the summer of 2012 I have to find female respondents to talk about their experience of WWII, but literally nobody wanted to talk to me. The archive is opened but sterile.

${ }^{22}$ The research of Elizabeth A. Kohn explains a lot of this mechanism: http://digitalcommons. law.ggu.edu/cgi/viewcontent.cgi? article $=1614 \&$ context $=$ ggulrev 
If one treats Sander's body of work as a metatext, her feminist preoccupations become glaringly evident. In an interview about her Liberators Take Liberties, Helke Sander said: "My approach in the film had been rather philosophical. I wanted to know what happens when a subject is repressed. I found out only in the course of my research that the rapes occurred on a massive scale, and I wanted to understand what this meant - when a subject that affects a lot of people isn't addressed in some kind of public forum"23. This philosophical approach let Sander equalize the victims on both sides of the conflict. She bridges the national divide with universal human relations. Sander challenged her spectators in the same way as Hiller challenged her readers. Both authors denied ethnic framing and pointed out the human qualities independent of ethnic roots.

That is why Barbara Kosta is partially right when she makes the following statement: "Because Sander misses opportunities to investigate the relationships of gender, ethnicity and war that structure the accounts of the women interviewed, she leaves undiscovered the intersection of biographical testimony, politics, and history" ${ }^{24}$. It was not the author's aim, however. By concentrating on national issues and patterns of individual and collective memory, the film might have lost its important message about the oppression of the subject in general, not only at the particular historical moment in one nation. Focusing on the issues of remembering might have blurred the author's questioning of the dichotomy "culture vs. nature."

The connection between Hiller's diary and Sander's film is present in their shared use of an objective tone applied to extremely subjective issues. Both works tend toward feminine genres, which provide enough leeway to maintain a personal point of view.

In her film, Sander follows the mode and general tone of the book A Woman in Berlin. It is unemotional, pointedly matter-of-fact. Like Hiller, Sander does not pass judgment; instead, she gives facts to the viewer, who is then free to draw her own conclusions. Even when she has some personal agenda, it is always espoused with great subtlety. For example, when a man in Minsk talked about the group rape he had participated in, Sander did not interrupt him: she listened and kept rolling. She included his voice without any commentary.

${ }^{23}$ Sabine Smith, "Interview with Helke Sander", in Triangulated Visions. Women in Recent German Cinema (Albany: State University of New York Press, 1998), 253.

${ }^{24}$ Barbara Kosta, “ Rape, Nation and Remembering History: Helke Sander's Liberators Take Liberties", in Gender and Germanness. Cultural Production of Nation (Providence, Oxford: Berghahn Books, 1997), 229. 
When Hiller writes about Russians (Soviets) and Germans, she foregrounds men's violence against women and women's survival strategies. Sander also emphasizes the women's defenselessness against men's power and speechlessness against social moral judgment, modeled by men in the patriarchal society. In the diary of Marta Hiller, the binary opposition "nature vs. culture' shapes the entire narration. The same issue comes up in Sander's film: "Was male sexuality, which belongs to the nature, or a will for a revenge, which is a part of patriarchal culture, the leading power in the mass raping during the end of WWII?"

When an archivist from the Berlin archive shows data on children born after the mass rape and fathered by Russians, Americans, and Englishmen, the spectators realize the universal nature of this evil. Though not immaterial, their ethnic background does not play a significant part in these cases. The issue of revenge for the atrocities inflicted upon Eastern Europe does not go entirely unmentioned, but the cases of rapes perpetrated by American and English men, rather than by the Germans, confer an extraordinary importance on their ethnic background and frame evil as an absolute devoid of national identity.

The feminist rhetoric of Sander's film has incited other activists to organize related oral history projects directed not only toward rethinking of the grisly 20th-century history in Central and Eastern Europe, but also toward transforming history into herstory, thereby opening the floor for, perhaps painful, discussion of the common German-Polish-Ukrainian past from a female perspective.

I would like to mention two films initiated by the Polish feminist organization in Krakow "Fundacja Kobieca" ("Women's Foundation") and realized by an international team of young women from Germany, Poland, and Ukraine. The first film, Jugow: Memory and Oblivion: Stories of Resettled Women, was made in a small Polish small town, Jugow (former Hausdorf), in $2010^{25}$. The second film, Railway Station Krasne-Busk. Stories of Resettled Women, was filmed in the small Ukrainian town of Busk in 2012 26 . Both films evoke some traumatic moments in personal and collective memory, but the feminist approach prevents the authors from discussing national guilt and the necessity of retribution. "The oppressed subjects," their dignity thwarted, are shown as an undifferentiated group of survivors, although one would think their ethnic identity would have been key in both stories, since it did precipitate their displacement.

\footnotetext{
${ }^{25}$ Here is the trailer: http://www.youtube.com/watch?v=6K4vmnjQ3MU

${ }^{26} \mathrm{http}: / /$ www.youtube.com/watch? $\mathrm{v}=6 \mathrm{~K} 4 \mathrm{vmnjQ} 3 \mathrm{MU}$
} 
Helke Sander's feminist film has made an indelible mark on the nonfiction filmmaking scene. Women and children as the weakest members of patriarchal society were the most important players in her metatext. In her Liberators Take Liberties, the feminist approach is rendered visible to the point of graphic. Sander challenged her spectators in the same way Hiller had challenged her readers. Both authors denied ethnic framing and pointed out the human qualities which were not dependent on ethnic roots. This attitude is more constructive not only for rethinking the shared past, but also for building a common future.

\section{A Woman in Berlin in Male Interpretation}

In 2008 Max Farberbock made a film based on Hiller's A Woman in Berlin. It is a narrative feature, possibly a masterpiece in the heritage movie genre. From such a markedly intimate, feminine work as Hiller's diary, Farberbock wove a typically male epic drama ${ }^{27}$.

The main difference between Sander's and Farberbock's approaches is not the generation gap (Farberbock began his career in the 1990s, while Sander belongs to the protesting generation of the 1960s); the largest divide lies between male and female forms of narration. The intimate form of first-person narration here finds itself transmuted into third-person generalities, a reduction made plain in the film's editing strategies. Typically, the narration starts with the heroine's voice, allowing the spectator to see everything through her eyes, and then switches to an impersonal camera angle, from which the heroine constitutes merely one of the frame's many components.

The spectators can hear Marta Hiller's voice (the book is extensively quoted in the movie), but very smoothly, the first-person narration loses its confiding disposition superseded by broad, authoritative statements. The first-person voice usually comes in the plural "we," when in the book it is mostly the singular "I." As a result of this seemingly minor alteration, the main narration forfeits its much-needed capacity for empathy. The third person appears, in general, as "they." "He" is rarely heard.

Helke Sander used actual newsreels in her film: the devastated hellscape of Berlin; corpses of dead women in Germany and in Russia; Soviet troops marching down the streets of Berlin; American propaganda advocating caution in intercourse with local women. However, all these non-fictional insertions, ultimately, bend to the will of a powerful and singular personal voice.

${ }^{27}$ Eagleton, Genre and Gender, 252. 
Max Farberbock did almost the same. He reenacted well-known chronicles and illustrated them with excerpts from the diary. And yet, the effect that he courts is diametrically opposed to Sander's. The narrator's voice becomes little more than a mouthpiece rattling off political cant. There is some aesthetic and ideological sense to staging mass scenes as caricatures, and it produces the anticipated effect on the horizon of the viewer's aesthetic expectations. Consequently, the individual voice of the first-person narration is lost.

Max Farberbock utilizes a binary opposition, too. In contrast to Helke Sander's film, his main dichotomy is German vs. Soviet, rather than male vs. female. The revenge discourse is powerful in the work of the male filmmaker. The plural form of the narration meshes well with the issue of collective crime and collective punishment. Thus, women and children receive the double stigma, both as women and as German citizens.

He also elicits empathy as he seeks to commiserate with the German men, a sentiment almost absent in the written document. Some scenes are unabashedly tailored for the mass audiences, especially the ones in which women chat about their sexual experiences and make jokes about the Soviet soldiers' lack of sexual fantasies and the German men's dubious virility.

In the film, Farberbock tries to smooth over all the jagged edges of the inter-German relationships mentioned in Hiller's book. She wrote that people were afraid for themselves and did not always help others in critical situations: "You pigs! Here they rape me twice in a row and you shut the door and leave me lying like a piece of dirt!" 28 It is not easy to recognize, but such situations are, after all, recognizable in their stark humanity. They do, however, alleviate the tension between "one's own people" and "the enemy." So, it is no surprise that Farberbock did not include such "shameful" moments in his masterpiece, for fear they might have diluted the main ideological message and unsettled the binary opposition between "one's own" and "others."

The generic laws of drama necessitate a love story. The narrator writes her diary thinking of her beloved Herd and sending notes to him, but it is not enough for the filmmaker who tries to convince the viewer that the main female character falls in love with her (most powerful) male counterpart. The romantic subplot is the weakest part of the movie because it stretches the limits of credibility, especially under the circumstances and in so short a time, and the actors confirm the improbability of romance, completely absent in the book, with stilted performances.

${ }^{28}$ A Woman in Berlin, 54. 
The ending of the film is also motivated by the general ideological message rooted in the chosen form. It leaves the spectator with the feeling that the main tragedy in the heroine's life is that Herd has abandoned her. It simplifies the main drama of dehumanization: "I do not have time for feeding my soul. ...God knows what we'll all end up eating. I think I'm far from any life-threatening extreme, but I don't really know how far. I only know that I want to survive - against all sense and reason, just like an animal"29. During the eight weeks she spent in the conquered city, a brilliant intellectual woman devolved into an animal. Maslow's hierarchy of needs might be illustrated by this statement. But, of course, such deterioration cannot be shown in a mainstream film meant to dispense transparent cause-and-effect relations.

The film A Woman in Berlin was a co-production of Germany, Poland, and Russia. Undoubtedly, film historians will analyze this phenomenon yet, but in my view, it has introduced a new stage in dealing with the resonances of WWII in Central-European cinema. The film's release was followed, in Russia as well as in Poland, by a series of sophisticated, revisionist accounts of WWII memories made in co-production with Germany: In the Darkness (2011) directed by Agnieszka Holland (Poland, Germany, Canada); 4 Days in May (2011) directed by Achim von Boris (Germany, Russia, Ukraine); In the Fog (2012) directed by Sergey Loznica (Germany, Netherlands, Belarus, Russia and Latvia); White Tiger (2012) directed by Karen Shakhnazarov (Russia, Germany). The list is incomplete, but it reflects a positive tendency in heritagefilm production. The former enemies are rethinking their shared past and try to find a common ground in the name of the future. Having read numerous discussions on the Internet forums concerning these films (including A Woman in Berlin), I have to admit that making a successful war film seems easier than waking the public opinion from the inert slumber formed by decades of ideological enmity. Furthermore, the exploitation of the binary opposition "one's own"-"enemies"/“Nazi"-"Soviet" does little to improve the situation. Conversations about WWII are inextricably linked to the search for untested, imaginative narrative techniques.

This paper was focused on the investigation of how the genre dictates the ideological message of the story. The hypothesis was borne out by a comparative analysis of Helke Sander's documentary Liberators Take Liberties (1991-1992) and Max Farberbock's narrative feature A Woman in Berlin (2008). Both films were analyzed in relation to the war-time diary A Woman in Berlin. Eight weeks in the Conquered City (1953).

${ }^{29}$ A Woman in Berlin, 261. 
In conclusion, I want to underline that dealing with the same time period and the same historical material, Sander chooses to focus on the ignominy of rape and the dramatic female experience in wartime, whereas Farberbock draws attention to the compensations of cross-national revenge. Sander's work is intentionally put in dialogue with Marta Hiller's diary, while Farberbock uses the text to spin a grand narrative of the end of WWII. Both films have facilitated further developments in their respective genres. Helke Sander has influenced the landscape of the feminist documentary, and Max Farberbock has ushered in a new phase in heritage film production.

\section{Rezumat}

Cuvinte-cheie: Al Doilea Război Mondial, filme documentare, jurnale, feminism, viol

Scopul articolului este de a arăta modul în care genul ales de producătorul unui film modelează discursul de bază a unui film. Autoarea compară filmul documentar a lui Helke Sander intitulat Eliberatorii ne iau libertatea (1991-1992) și filmul documentar a lui Max Farberbock O Femeie in Berlin, ambele axându-se asupra impactului ultimei perioade a celui De-al Doilea Război Mondial asupra femeilor germane. Este vorba în special de violarea femeilor germane de către Aliații occidentali, o temă care devine subiect public odată cu publicarea volumului anonim O femeie din Berlin (1953). Există o legătură directă între cele două filme și carte, dar există și deosebiri: Sander pune în centrul atenției însăși violurile și experiența femeilor în război, în timp ce Farberbock este preocupat mai mult de răzbunare ca fenomen transnațional. Autoarea analizează îndeaproape elementele care țin de caracterul (genul) jurnalului, de filmul documentar (feminist) şi de narațiunea filmului. Ulterior, autoarea oferă unele paralele între filmul lui Helke Sander și jurnalul O femeie la Berlin și discută cele două documentare în contextul feminist inspirat de realizarea lui Sander. 